NASA/TM-2005-213991

\title{
A Design of a Modular GPHS-Stirling Power System for a Lunar Habitation Module
}

Paul C. Schmitz

Power Computing Solutions, Inc., Avon, Ohio

L. Barry Penswick

Sest, Inc., Middleburg Heights, Ohio

Richard K. Shaltens

Glenn Research Center, Cleveland, Ohio 
Since its founding, NASA has been dedicated to the advancement of aeronautics and space science. The NASA Scientific and Technical Information (STI) Program Office plays a key part in helping NASA maintain this important role.

The NASA STI Program Office is operated by Langley Research Center, the Lead Center for NASA's scientific and technical information. The NASA STI Program Office provides access to the NASA STI Database, the largest collection of aeronautical and space science STI in the world. The Program Office is also NASA's institutional mechanism for disseminating the results of its research and development activities. These results are published by NASA in the NASA STI Report Series, which includes the following report types:

- $\quad$ TECHNICAL PUBLICATION. Reports of completed research or a major significant phase of research that present the results of NASA programs and include extensive data or theoretical analysis. Includes compilations of significant scientific and technical data and information deemed to be of continuing reference value. NASA's counterpart of peerreviewed formal professional papers but has less stringent limitations on manuscript length and extent of graphic presentations.

- TECHNICAL MEMORANDUM. Scientific and technical findings that are preliminary or of specialized interest, e.g., quick release reports, working papers, and bibliographies that contain minimal annotation. Does not contain extensive analysis.

- CONTRACTOR REPORT. Scientific and technical findings by NASA-sponsored contractors and grantees.
- CONFERENCE PUBLICATION. Collected papers from scientific and technical conferences, symposia, seminars, or other meetings sponsored or cosponsored by NASA.

- SPECIAL PUBLICATION. Scientific, technical, or historical information from NASA programs, projects, and missions, often concerned with subjects having substantial public interest.

- TECHNICAL TRANSLATION. Englishlanguage translations of foreign scientific and technical material pertinent to NASA's mission.

Specialized services that complement the STI Program Office's diverse offerings include creating custom thesauri, building customized databases, organizing and publishing research results ... even providing videos.

For more information about the NASA STI Program Office, see the following:

- Access the NASA STI Program Home Page at http://www.sti.nasa.gov

- E-mail your question via the Internet to help@sti.nasa.gov

- Fax your question to the NASA Access Help Desk at 301-621-0134

- Telephone the NASA Access Help Desk at 301-621-0390

- Write to:

NASA Access Help Desk

NASA Center for AeroSpace Information 7121 Standard Drive

Hanover, MD 21076 
NASA/TM-2005-213991

\section{A Design of a Modular GPHS-Stirling Power System for a Lunar Habitation Module}

\section{Paul C. Schmitz}

Power Computing Solutions, Inc., Avon, Ohio

L. Barry Penswick

Sest, Inc., Middleburg Heights, Ohio

Richard K. Shaltens

Glenn Research Center, Cleveland, Ohio

Prepared for the

Third International Energy Conversion Engineering Conference sponsored by the American Institute of Aeronautics and Astronautics San Francisco, California, August 15-18, 2005

National Aeronautics and

Space Administration

Glenn Research Center 


\section{Acknowledgments}

The work described in this paper was performed for the Exploration Systems Mission Directorate (ESMD) and the Radioisotope Power System (RPS) Program, which provided funding for these projects.

This report contains preliminary

findings, subject to revision as analysis proceeds.

Available from

NASA Center for Aerospace Information 7121 Standard Drive

Hanover, MD 21076
National Technical Information Service 5285 Port Royal Road Springfield, VA 22100 


\title{
A Design of a Modular GPHS-Stirling Power System for a Lunar Habitation Module
}

\author{
Paul C. Schmitz \\ Power Computing Solutions, Inc. \\ Avon, Ohio 44011 \\ L. Barry Penswick \\ Sest, Inc. \\ Middleburg Heights, Ohio 44130 \\ Richard K. Shaltens \\ National Aeronautics and Space Administration \\ Glenn Research Center \\ Cleveland, Ohio 44135
}

\begin{abstract}
Lunar habitation modules need electricity and potentially heat to operate. Because of the low amounts of radiation emitted by General Purpose Heat Source (GPHS) modules, power plants incorporating these as heat sources could be placed in close proximity to habitation modules. A design concept is discussed for a high efficiency power plant based on a GPHS assembly integrated with a Stirling convertor. This system could provide both electrical power and heat, if required, for a lunar habitation module. The conceptual GPHS/Stirling system is modular in nature and made up of a basic $5.5 \mathrm{KWe}$ Stirling convertor/GPHS module assembly, convertor controller/PMAD electronics, waste heat radiators, and associated thermal insulation. For the specific Lunar application under investigation eight (8) modules are employed to deliver $40 \mathrm{KWe}$ to the habitation module. This design looks at three levels of Stirling convertor technology and addresses the issues of integrating the Stirling convertors with the GPHS heat sources assembly using proven technology when ever possible. In addition, issues related to the high-temperature heat transport system, power management, convertor control, vibration isolation, and potential system packaging configurations to ensure safe operation during all phases of deployment will be discussed.
\end{abstract}

\section{Introduction}

Lunar habitation modules would require significant amounts electricity to operate. While GPHS has been used for years on NASA's deep space missions due to their expense and limited availability of these units power levels of greater than $1 \mathrm{KWe}$ have not been available. Advances in Stirling technology however, could allow very efficient use of the GPHS generated heat and provide a reasonable path to producing significant amounts of power on the lunar surface. NASA'S recent Cassini spacecraft had 3 Radioisotope Thermoelectric Generators (RTG's) that produced 850 watts of electrical power. Each RTG has 18 GPHS modules for a total launched GPHS inventory of 54 GPHS modules. Converting to a high efficiency Stirling convertor should allow a nearly 5-fold increase in electrical output with the same GPHS thermal power input. For this design concept the GPHS modules are linked to the Stirling convertor via a radiative coupling while using a sodium $(\mathrm{Na})$ thermal siphon in the lunar gravity environment to move the heat. When operating on the lunar surface the GPHS heat source assembly would be on the bottom. The GPHS modules would boil the sodium in the pipes, which results in the Na rising and condensing on a radiative surface at the top of the assembly. The Stirling convertor is set above the heat source assembly with a corresponding lower temperature radiative collector surface integrated into the Stirling heater head. This would serve as both the mechanism for transferring heat to the Stirling and to concentrate the heat in the small surface area of the Stirling heater head. Heat is rejected at the cold end of the Stirling convertor using a liquid water pumped loop. Because of the relatively low amount of radiation emitted by GPHS modules the power plants could be placed in close proximity of the habitation modules. This design looks at three levels of Stirling convertor technology and integrates these Stirling convertors with the radioisotope (GPHS) heat sources. The GPHS heat sources are integrated with the Stirling convertors using heat pipes and the heat is rejected form the convertors using a pumped liquid loop. 


\section{Stirling Convertor}

The performance, specific power, and reliability of free-piston Stirling cycle power conversion systems have improved dramatically in the past decade due a combination of maturing technology and the realization that the development of a convertor must be closely integrated with other elements of the system to provide stable and reliable power to the end user. As an example of these improvements in the space power area, hardware developments in support of NASA/DOE (ref. 1) has resulted in convertors with overall thermal to electric efficiencies approaching 40 percent, specific mass levels $<10 \mathrm{Kg} / \mathrm{KWe}$ at power levels on the order of $100 \mathrm{We}$ (ref. 2), These high convertor efficiencies result in GPHS loading requirements on the order of $1 / 4$ to $1 / 5$ that of comparable RTG systems. In addition, efforts are currently under way at NASA/GRC and other groups (ref. 3) to further improve on convertor performance parameters without impacting convertor durability and reliability.

While current Stirling convertor efforts have focused on the use of a small number of GPHS modules (1 to 2) to provide the thermal energy, there is no fundamental reason that larger numbers of GPHS modules could not be used to provide power levels in the KWe range. This concept has a number of advantages compared to other power generation schemes: 1) the GPHS module is fully defined and space launch qualified, 2) emitted radiation is very low and would allow easy access and placement of the system close to the end user, 3) heat source development costs will be low, and 4) the GPHS heat source can be easily simulated with electrical heaters allowing extensive life testing in existing facilities. The negative aspects of GPHS modules are the cost and the limited supply.

Table 1 defines the basic Stirling convertor and/or GPHS related parameters employed in the evaluation process. As noted previously these parameters are based on currently demonstrated hardware or technology under active development at this time.

Table 1.-Evaluation Parameters

\begin{tabular}{|l|l|}
\hline \multicolumn{1}{|c|}{ Parameter } & \multicolumn{1}{c|}{ Nominal Value or Range } \\
\hline Net electrical power to habitat & $5.0 \mathrm{KWe}$ \\
\hline Controller/PMAD efficiency & 0.93 \\
\hline Stirling convertor electrical output & $5.5 \mathrm{KWe}$ \\
\hline Effective hot end temperature & 925 to $1275 \mathrm{~K}\left(650\right.$ to $\left.1000{ }^{\circ} \mathrm{C}\right)$ \\
\hline Effective cold end temperature & $>350 \mathrm{~K}$ \\
\hline GPHS maximum operating temperature & 1275 to $1375 \mathrm{~K}\left(1000\right.$ to $\left.1100{ }^{\circ} \mathrm{C}\right)$ \\
\hline
\end{tabular}

From the viewpoint of the convertor the parameters having the greatest impact on performance and specific mass, are 1) heater head ("hot end") temperature, 2) rejection ("cold end") temperature, 3) alternator characteristics, and 4) interface with the heat source (GPHS modules). Because of radiator and sink temperature constraints on size and mass, the effective cold-end temperature of the convertor was constrained to temperatures greater than $350 \mathrm{~K}$. The cold-end temperature impacts the convertor in two ways: 1) as the cold-end temperature increases, for a fixed hot-end temperature, the effective cycle temperature ratio falls reducing performance and 2) at temperatures exceeding approximately $400 \mathrm{~K}\left(125^{\circ} \mathrm{C}\right)$ the current high performance $\mathrm{NdFeB}$ magnets employed in the linear alternator have reached their upper operating temperature limit. The latter will require the change to the SmCo magnet material that results in somewhat larger and heavier linear alternators. Since the linear alternator makes up approximately 60 to 70 percent of the convertor mass, this increase becomes an important factor in evaluation of convertor options.

Stirling convertor performance is shown in Figure 1 as a function of effective cycle temperature ratio for the $375 \mathrm{~K}\left(100^{\circ} \mathrm{C}\right)$ rejection temperature. Techniques employed to define convertor efficiencies take into account thermodynamic cycle losses, alternator losses, along with all thermal parasitic losses and have proven to be quite accurate based on a number of hardware development efforts. The vertical lines represent the corresponding temperature ratios at the heater head temperatures noted. The lower heater head temperature $\left(650{ }^{\circ} \mathrm{C}\right)$ is representative of late $1990^{\prime}$ 's technology, the mid temperature $\left(850^{\circ} \mathrm{C}\right)$ hardware currently in development and is 


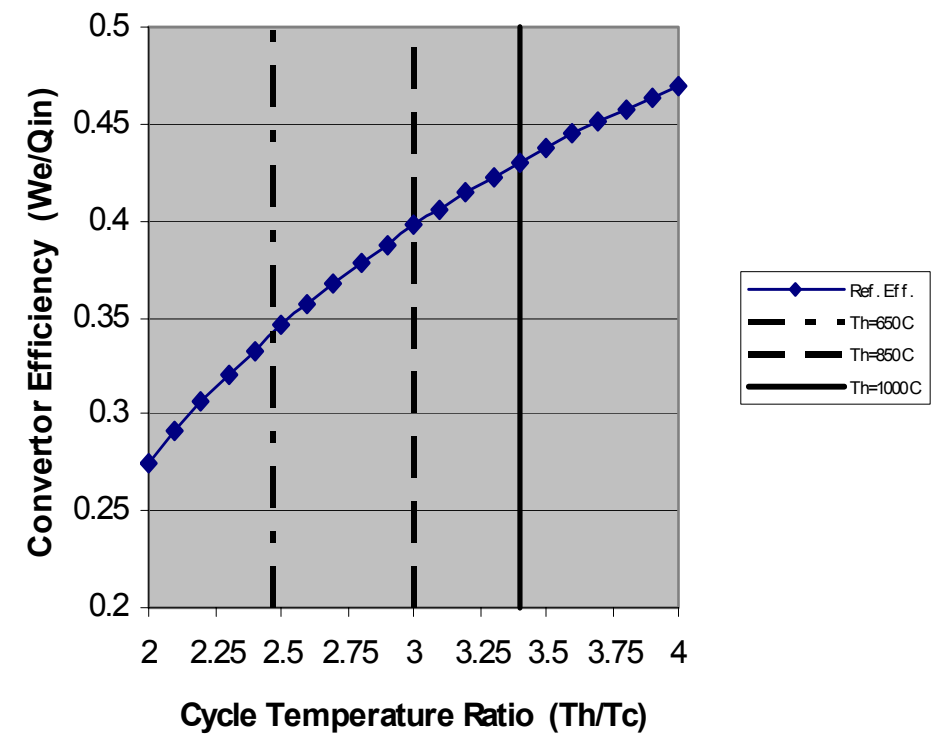

Figure 1.-Convertor performance versus cycle temperature ratio, cold end temperature $375 \mathrm{~K}$.

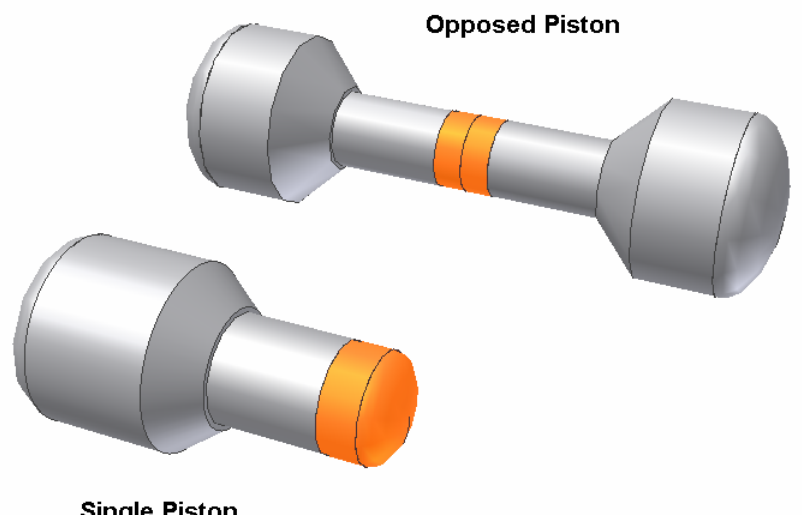

Figure 2.-Convertor configurations.

employed as the reference point for the proposed system, and the highest temperature $\left(1000{ }^{\circ} \mathrm{C}\right)$ representative of advanced developments incorporating ceramic materials. In the case of the highest heater head temperature, the issue of maximum GPHS operating temperature must be considered. Current estimates place this limitation in the 1275 to $1375 \mathrm{~K}\left(1002\right.$ to $\left.1102{ }^{\circ} \mathrm{C}\right)$ range which, when combined with a HTS temperature drop conservatively set at $100{ }^{\circ} \mathrm{C}$, yield maximum heater head temperatures in the 1175 to $1275 \mathrm{~K}$ (900 to $1000{ }^{\circ} \mathrm{C}$ ) range. Increasing the effective rejection temperature essentially "slides" the heater head temperature lines to the left to lower effective temperature ratios.

The schematic shown in Figure 2 provides a description of the basic configuration and size of the two options for the proposed Stirling conversion system. The pool boiler and associated thermal insulation has been removed for clarity. The single cylinder configuration is representative of current small space engines (for the SRG two single cylinders engines not sharing a common expansion space are placed end-to-end), while the opposed piston configuration (common expansion space) has been employed in multi KWe development programs (ref. 4). The opposed piston configuration is inherently dynamic balanced eliminating the need for a separate vibration isolation system but 
represents a more complex interface between the convertor HTS and the heater head assembly. The single cylinder configuration, which was selected as the reference configuration for analysis purposes, employs a simple monolithic heater head. The latter acts as the condenser surface for the pool boiler employed to transfer the thermal energy from the GPHS assembly to the convertor. However, since this type of convertor is not dynamically balanced, either a passive or active vibration isolation system would be employed. For simplicity, the isolator would be located within the convertor pressure vessel. The use of this type of isolation system does impact the mass of the convertor by approximately 10 percent. Convertor specific mass for the single cylinder configuration, including the required vibration isolation system, is estimated at $8.25 \mathrm{Kg} / \mathrm{KWe}$ yielding a convertor mass of $45 \mathrm{Kg}$, overall length of $480 \mathrm{~mm}$ and a maximum diameter of $230 \mathrm{~mm}$. The opposed piston configuration is slightly heavier at $51 \mathrm{Kg}$ and somewhat larger ( $745 \mathrm{~mm}$ long by $215 \mathrm{~mm}$ maximum diameter). It is important to note that the convertor performance is identical for both and the impact on system mass of changing between the two configurations is minimal.

To function in a stable and efficient manner the free-piston Stirling convertor must be actively controlled. The convertor controller would provide the capability to vary power piston amplitude so as to maintain the design operating temperature for the heater under all operating conditions, In addition the controller would adjust the convertor electrical power factor without the need for large external capacitors and monitor/control the convertor vibration levels. As a final feature, the system would carry out the necessary power conditioning activities so that the regulated 160 volt output is available to the end user.

\section{Heat Transport System}

As noted previously, a driving factor in the concept evaluation process was the use of proven or low risk technology whenever possible. A number of alternative configurations were considered ranging from a direct coupling of the GPHS assembly to the convertor heater head via heat pipes to conductively coupling the convertor to various GHPS HTS configurations. The HTS must effectively couple the GPHS assembly with the convertor with minimum thermal losses. Since the system would operate in a lunar gravity field it would be possible to employ gravity assisted HTS concepts such as a pool boiler or thermosyphon rather than pure heat pipes can be employed. This minimizes issues concerning the lifetime reliability of the capillary wick materials required for successful heat pipe operation. As shown schematically in Figure 3 the GPHS portion of the HTS is made up of 6 individual boiler "pipes" (one shown mounted and another alone for clarity) which employ $\mathrm{Na}$ as a working fluid and are attached to the carbon composite thermal support structure carrying the GPHS modules. Since the evaporator portion of the boiler can be of any configuration it is formed as a curved panel that effectively couples two stacks of GPHS modules to a single pipe. The individual modules are "clocked" such that the maximum number of GPHS modules are served by an individual boiler pipe. The 6 pipes are attached to the backside of a carbon composite plate that that serves as the radiator for the radiative coupling to the convertor. This surface provides the hot surface of the radiation-coupling feature of the proposed concept.

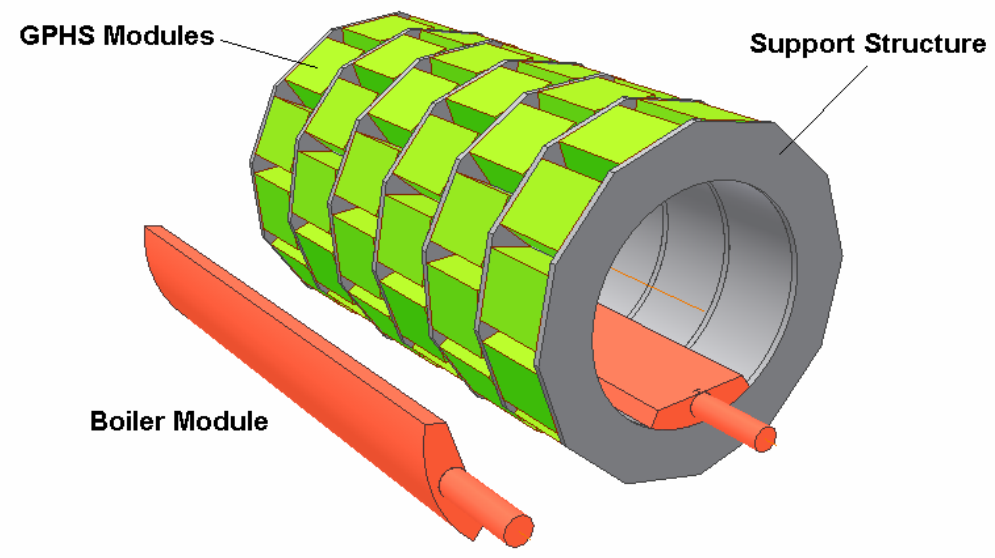

Figure 3.-GPHS HTC configuration. 


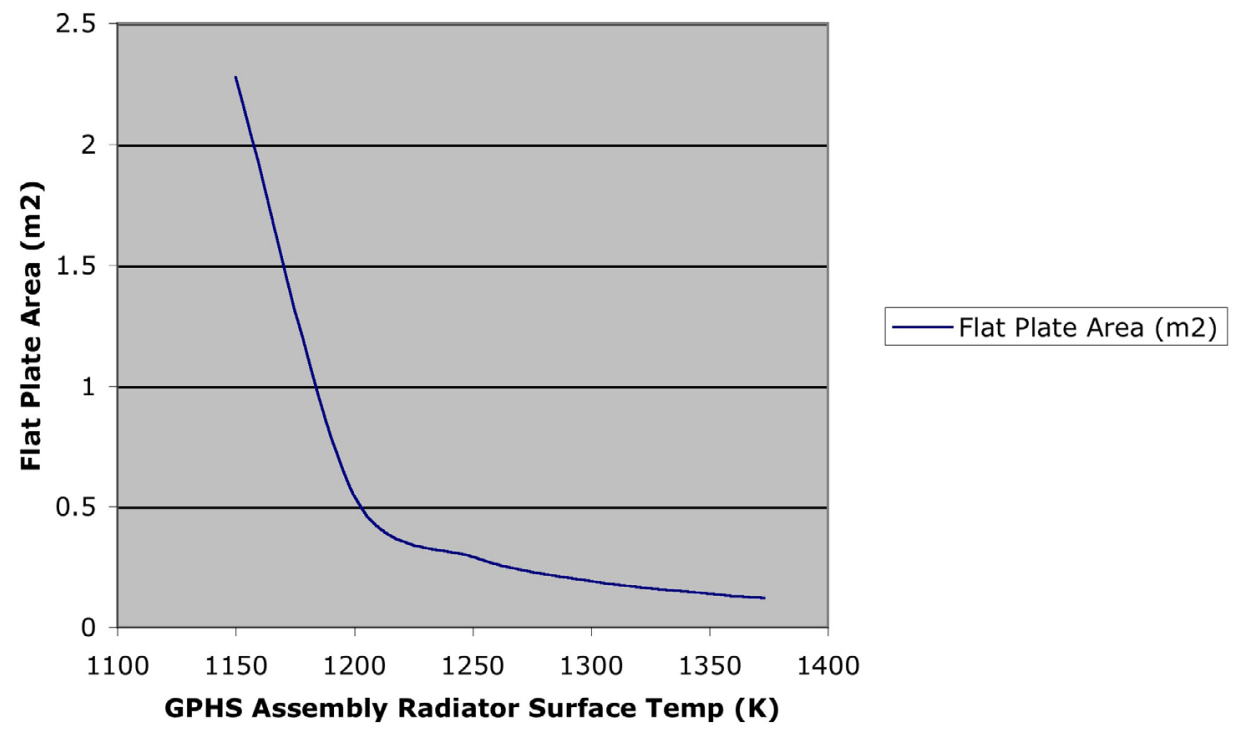

Figure 4.- Radiator size requirements.

The convertor side HTS would also employs a pool boiler and is based on existing technology. The face of the boiler acts as the "cold" receiver, with the boiling of the $\mathrm{Na}$ working fluid occurring on the rear side. Vapor from the boiler condenses on the convertor heater head with the liquid condensate falling, under the influence of gravity, back to the boiler surface.

To provide maximum utility the thermal energy flow between the GPHS assembly and the convertor is via radiation across a relatively narrow gap. Based on thermal power requirements, and the reference convertor heater head operating temperature, $1123 \mathrm{~K}\left(850^{\circ} \mathrm{C}\right)$, the surface area required for the radiator can be defined as a function of GPHS operating temperatures, see Figure 4. Based on existing GPHS module operating temperature constraints a radiator surface area of approximately $0.25 \mathrm{~m}^{2}(0.5 \mathrm{~m}$ diameter $)$ would be required which also defines the convertor pool boiler diameter. It is important to note that under these operating conditions both pool boiler condenser/evaporator flux levels are quite low, $<5 \mathrm{~W} / \mathrm{cm}^{2}$, providing significant operating margin based on the Na working fluid limits. While not specifically used as a HTS system design criteria, the radiation coupling does allow the convertor/GPHS assembly to be decoupled. This would allow for convertor replacement or transport to different sites on the lunar surface.

\section{System Operation}

The use of the combined pool boiler/radiation coupled GPHS heat source/convertor configuration would provide a high degree of reliability when operating in the lunar gravity field. However, while in transient neither of the two pool boilers would function under "zero g" conditions. Since the GPHS assembly is always generating thermal energy a technique must be employed to reject this energy to an alternative sink when the system is not producing power on the lunar surface. To remove this energy during times when the system is not producing power the insulation package surrounding the GPHS assembly would be "opened" allowing the thermal energy to be radiated to space eliminating the need for an independent radiator. A deployable HTS insulation disk would also be utilized to "fill" the gap between the GPHS radiator and the convertor absorber in the radiation-coupled portion of the HTS. The in transit (and after initial lunar landing) configuration of the system operating in this mode is noted in Figure 5. An additional aspect of this capability is that if convertor were to fail while on the lunar surface, the insulation could be deployed to reduce the non-functioning convertor hot-end temperature. 


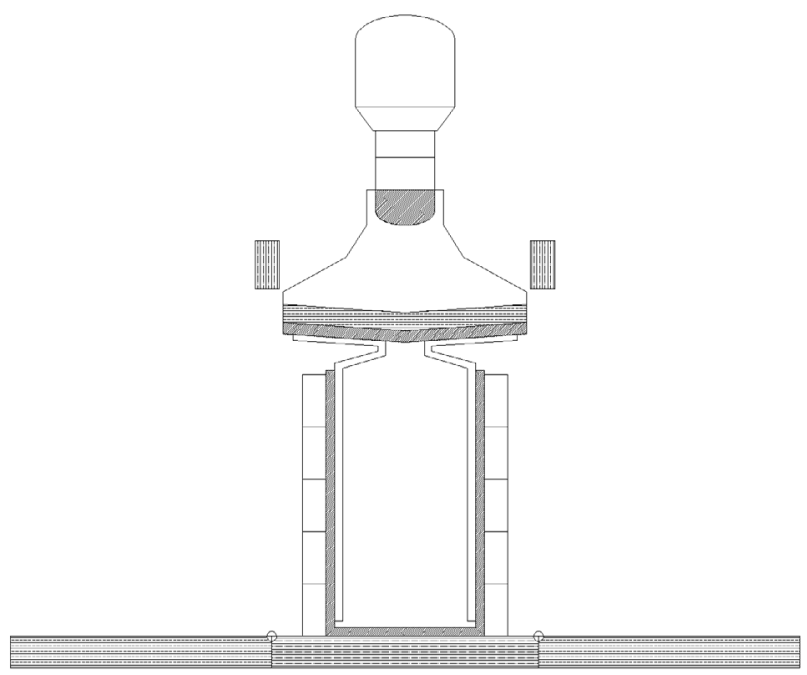

Figure 5.- In transit configuration-convertor not operating.

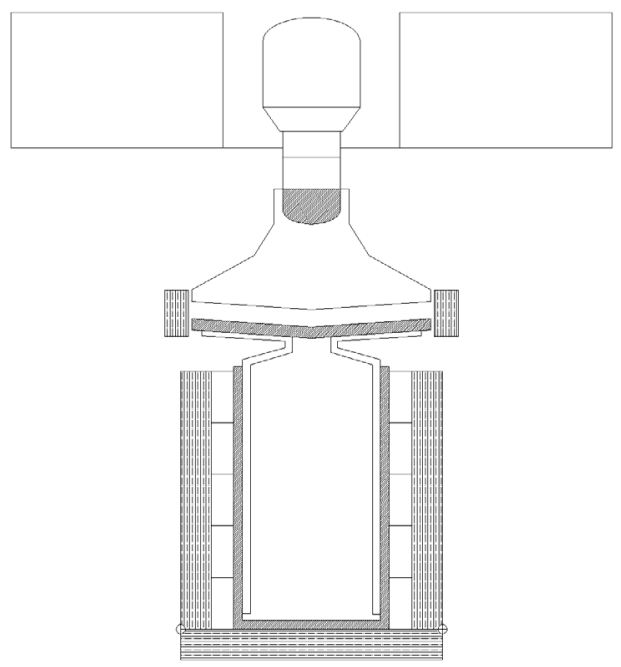

Figure 6.-System configuration during normal power generation—convertor operating.

Once the convertor heat rejection radiators are deployed and the HTS insulation disk removed, the GPHS insulation package is "closed" essentially forcing the thermal energy to flow to the convertor. The configuration of the system in this operating condition is noted in Figure 6.

\section{Power Management and Distribution}

The power management and distribution system first converts the low frequency AC power generated from the Stirling convertor to DC and then connects the eight (8) Stirling convertors together and moves to the habitat module. It was assumed for this study that the load for the habitat modules is 160 volts, the same as for the International Space Station. Figure 7 shows the electrical layout and efficiencies of the various components. Each Stirling has its own controller and AC to DC rectifier which converts the $100 \mathrm{~Hz}$ AC to the 160 volt direct current (DC) bus voltage. Each Stirling convertor is attached to common switchgear and remote bus isolator (RBI). The RBI 


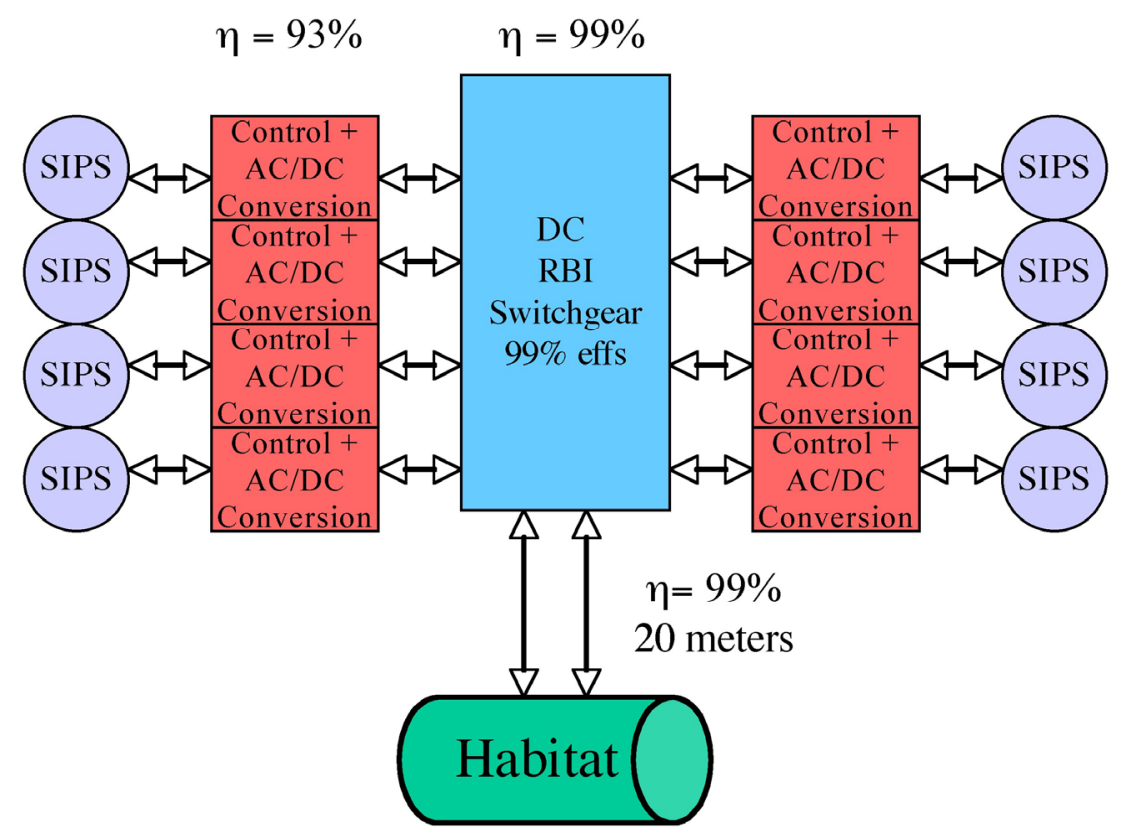

Figure 7.-Electrical layout and efficiencies-PMAD system.

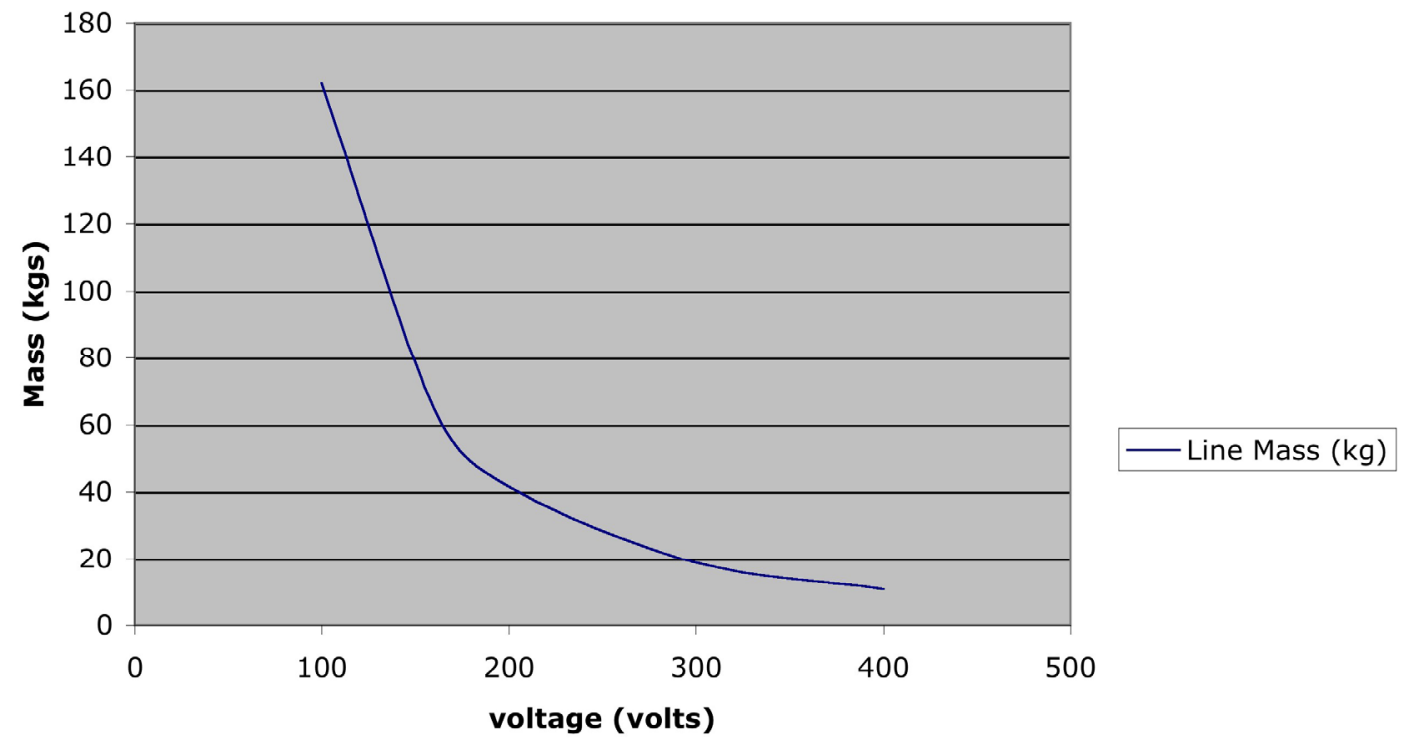

Figure 8. - DC Transmission line mass versus operating DC voltage.

switchgear allows the sources to be added or removed as desired without affecting the rest of the bus and the provides circuit protection in case of faults (ref. 5). The power is then sent to the habitat modules using aluminum conductors. Figure 8 shows the trade of cable mass as a function of voltage for a 1 percent loss. It is assumed that the habitat is 20 meters from the habitat module. Both the rectifiers and the cabling, RBI and switchgear are dual redundant in their configuration. The switchgear/RBI, cabling and the rectifier are modeled using the Rocketdyne model sited in the previous reference. Table 2 shows the mass breakdown for the cabling, remote bus interface and the switchgear. 
Table 2.-Mass breakdown

\begin{tabular}{|c|c|}
\hline Component & Total Mass (kg) \\
\hline DC /RBI Switchgear & $62 \mathrm{kgs}$ \\
\hline Cabling & $61 \mathrm{kgs}$ \\
\hline Totals & $\mathbf{1 2 3} \mathbf{~ k g s}$ \\
\hline
\end{tabular}

\section{Heat Rejection Subsystem—Radiator Cold End Fluids and Materials}

Power system operation on the lunar surface is a challenge because of the lack of atmosphere to reject heat and the wide range of heat rejection or sink temperatures, which occur during the lunar diurnal cycle. From both a cost and production standpoint the power system designer would want to minimize the amount of isotope required and for a thermodynamic cycle this requires low rejection temperatures. The penalty for this low rejection temperature is that the area required to reject the waste heat increases with decreasing rejection temperature. This trade between heat source mass and size and radiator size leads to mass minimums for the overall system. Studies analyzed the advantages and disadvantages of radiator orientation on the lunar surface (refs. 6 and 7). From these studies it was found that for vertically oriented radiators the maximum and minimum sink temperatures during lunar day/night cycle was about 180 to $314 \mathrm{~K}$ and between 180 and $270 \mathrm{~K}$ for horizontal radiators which don't see the lunar surface. The trade between the a two sided radiator operating at a higher sink temperature and a single sided radiator rejecting heat at a lower temperature may provide different answers depending on how little isotope is available or if the system is mass or area constrained. In addition, the large change in sink temperatures will result in changes in both the power output of the system and the temperature range requirements of the heat rejection system.

To reject the waste heat a pumped water loop is flown over the cold end of the Stirling convertor and then sent out to a water heat pipe radiator. Stirling convertors operate best when the inlet to exit coolant temperature difference is kept to a minimum. In general the temperature rise of a fluid used to remove the waste heat should be about $25 \mathrm{~K}$ or less to ensure no Stirling cycle performance penalty. The panel design, see Figure 9, selected is similar to that used on the space station which consists of heat pipes sandwiched between two outer face sheets. The two outer face sheets are used for the vertical radiator panels, for the horizontal radiator panels the bottom sheet is removed. Panel mass was approximately $3.5 \mathrm{~kg} / \mathrm{m}^{2}$ for the cases shown for the 2 -sided radiator and $2.3 \mathrm{~kg} / \mathrm{m}^{2}$ for a horizontal radiator. This number does not include the fluid ducts, fluid or pumps, which are accounted separately. The pump design selected is also scaled from that used on the space station and is scaled both in efficiency and mass to meet the pressure drop and flow rate requirements of the system. At lunar noon the temperature of the radiator without any heat should be that of the sink temperature (i.e., $270 \mathrm{~K}$ for the horizontal radiator and $314 \mathrm{~K}$ for the vertical radiator). In order to ensure that a thaw system is not necessary it is assumed that startup occur for the horizontal radiator case near lunar noon and for the vertical radiator nearly anytime after dawn. For the horizontal radiator case it may be necessary to increase the solar absorptivity of the horizontal radiator surface to raise its temperature, which would require a small increase in radiator area. For the vertical radiator surface the temperature is well above the melting point of water at 1 Bar. Figure 10 shows the sink temperature for a both a horizontal and vertical radiator on the lunar surface.

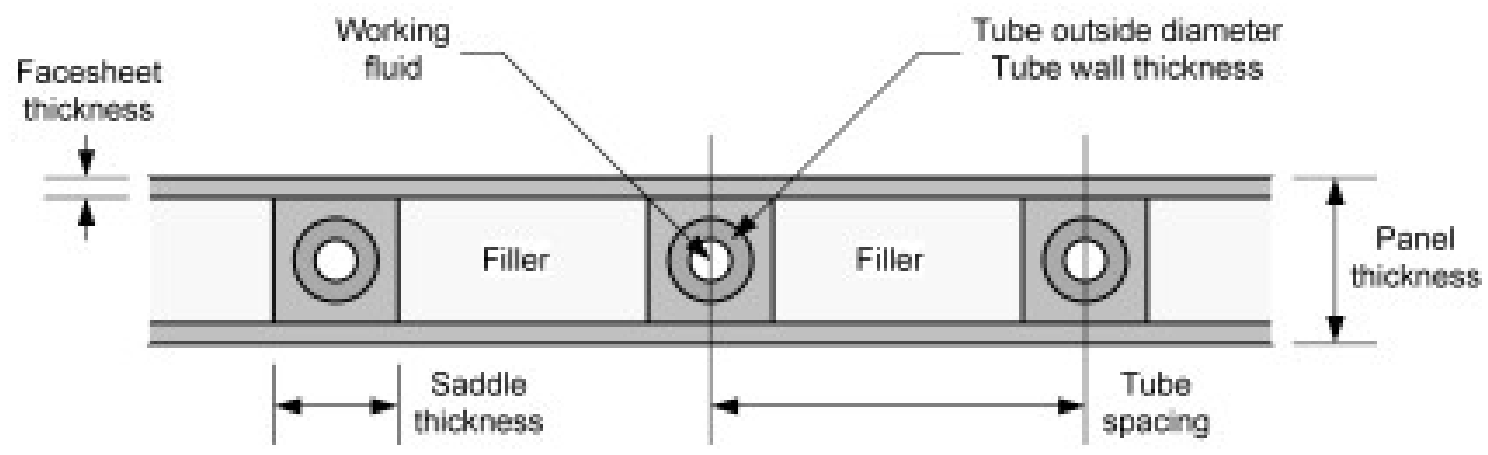

Figure 9.--Radiator configuration. 


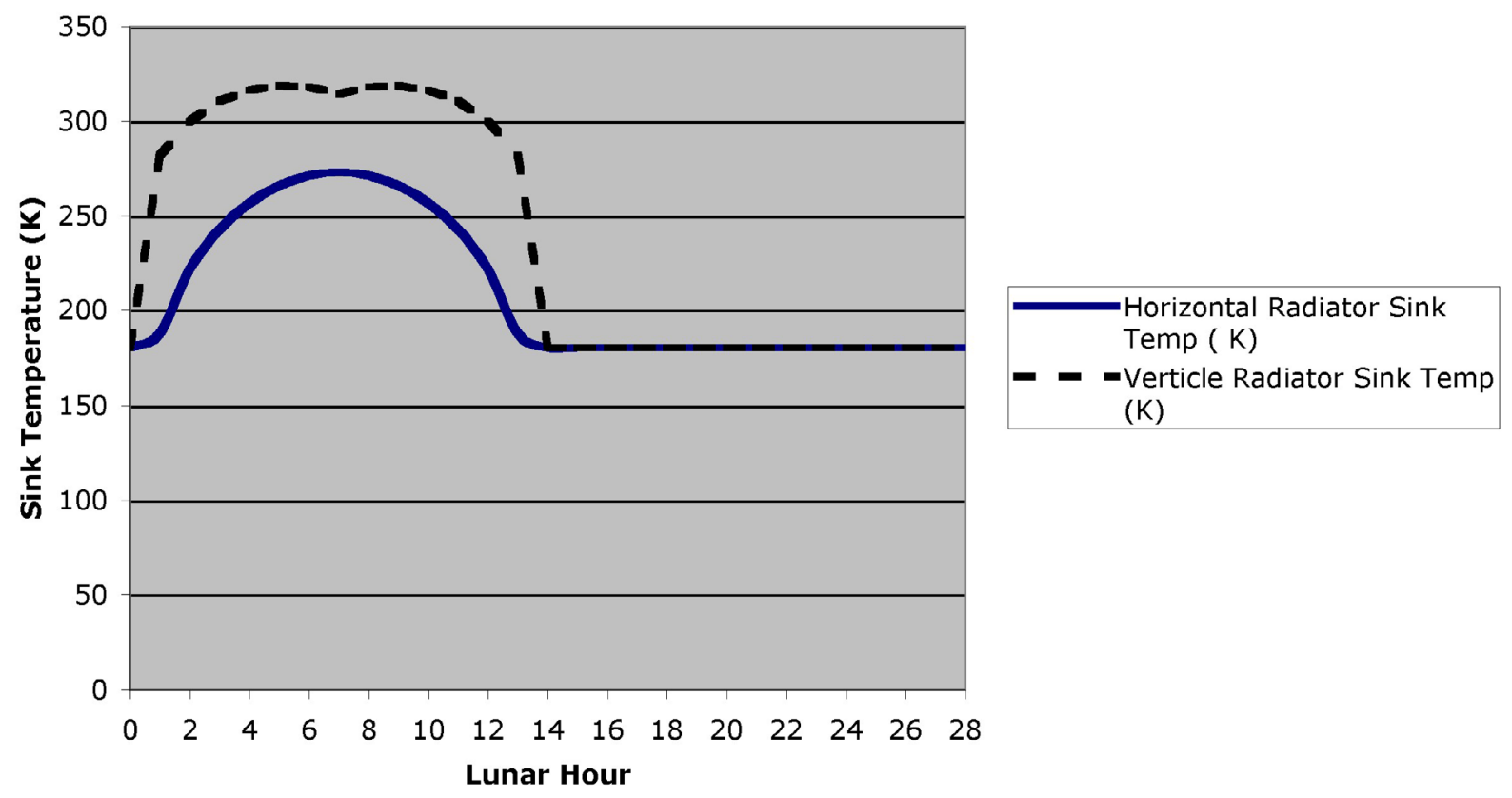

Figure 10.- Radiator sink temperature for horizontal and vertical orientations.

\section{System Trade Studies}

Trade studies for the isotope Stirling power systems were performed using different operating conditions (cold-end temperature, convertor design, etc.) and examining how each of these operating conditions affects the overall power plant. For each of the subsystems discussed previously, technology assessments were made regarding their developmental status and readiness for a conceptual near term lunar mission. Components were then modeled and parameters varied to understand how each impacts the system. As an example, a higher temperature ratio across the convertor would provide improved efficiency but will also in turn require a larger radiator. Due to high launch costs and limited lift capability, launch mass is often a parameter that is minimized. In this study in particular because of the high cost of GPHS total landed lunar costs were also considered. Additionally, radiator area, which is limited by volumetric constraints of the shroud of the launch vehicle, may prevent the power system from being able to operate at its minimum mass point.

Two technology baselines were considered which were discussed in more detail in the Stirling section of the report. Both 375 and $425 \mathrm{~K}$ cold end temperatures were considered for this report and reflect the current state-of-the-art. Both cases are discussed in this analysis. For both of these systems a reference heater head temperature of $1123 \mathrm{~K}$ $\left(850^{\circ} \mathrm{C}\right)$ was used.

\section{Results}

Figure 11 shows the mass and radiator area as a function of Stirling cold-end temperature for a $5 \mathrm{KWe}$ net output Stirling convertor system with both horizontal and vertical radiators. The mass cross over point between the radiator orientations occurs at a Stirling cold-end temperature of $430 \mathrm{~K}$. The reason for the crossover is the trade between a lower effective sink temperature with the horizontal radiator versus the two-sided radiator using vertical panels but with a higher sink temperature. If radiator deployed area is of primary concern this cross over between the two radiator orientations occurs at about $400 \mathrm{~K}$. For all cases the lower the rejection temperature the fewer GPHS modules required. 


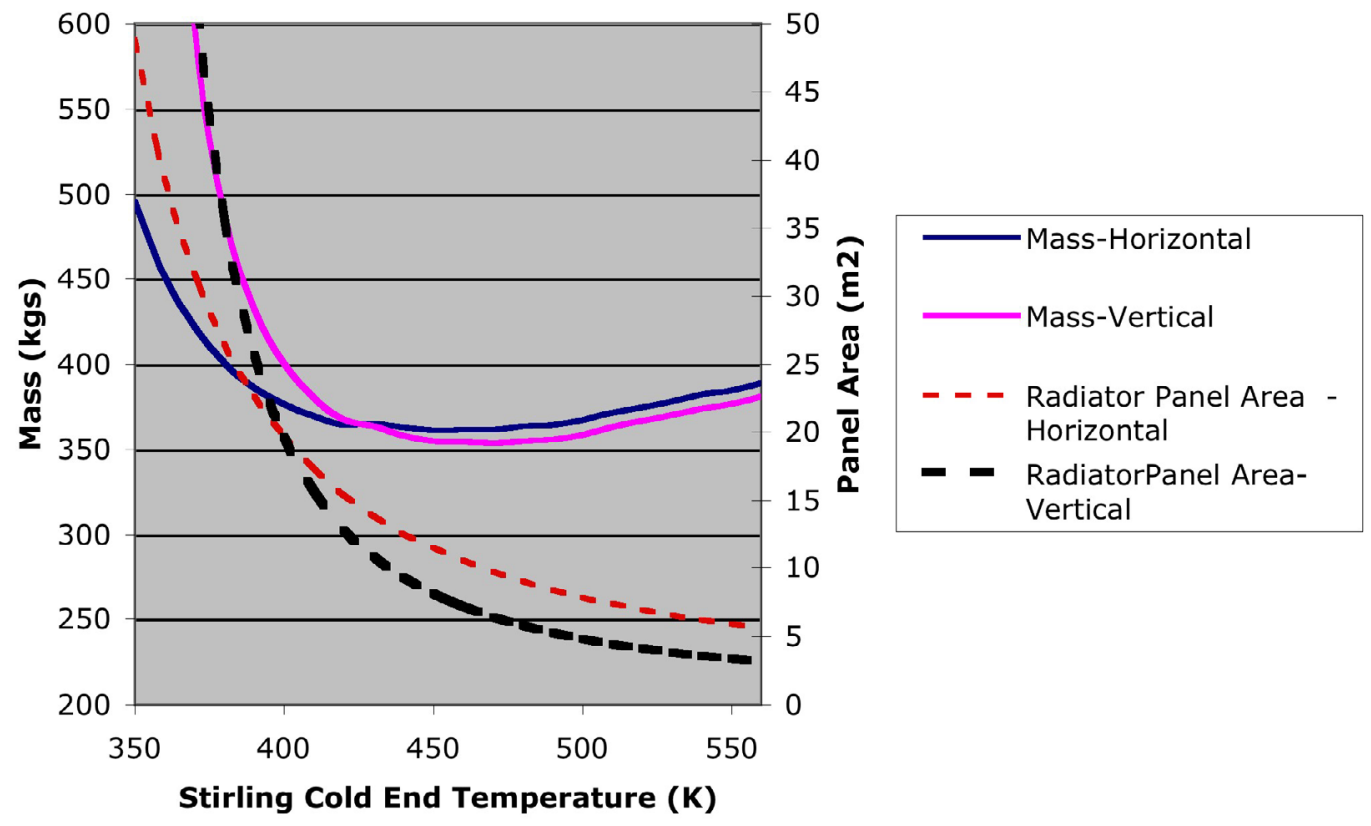

Figure 11. - Mass and radiator as a function of Stirling cold end temperature.

Table 3 shows a comparison of the 375 and $425 \mathrm{~K}$ cold end along with the minimum mass cases with both horizontal and vertical radiators. If the $375 \mathrm{~K}$ cold end Stirling is used it is preferable from system mass and radiator area to use a horizontal radiator. When using the high-temperature Stirling cold end (i.e., $425 \mathrm{~K}$ ) the vertical radiator orientation has a slight mass (352 vs. $366 \mathrm{kgs})$ and radiator panel area advantage $\left(15 \mathrm{vs} .11 .5 \mathrm{~m}^{2}\right)$. For the minimum mass cases both radiator orientations optimize to $450 \mathrm{~K}$ but the vertical radiator orientation has $25 \mathrm{~kg}$ mass advantage and a $3 \mathrm{~m}^{2}$ radiator panel advantage. To keep mass relatively close to its minimum, Stirling cold-end temperatures should not fall below about $360 \mathrm{~K}$ before a rapid increase in system mass occurs due to a increasing heat rejection area and mass. Figure 12 shows both system mass and GPHS count as a function of Stirling cold-end temperature for a horizontal radiator configured $5 \mathrm{KWe}$ system. GPHS module count would rise linearly with increasing temperature but system mass rapidly increases below about $360 \mathrm{~K}$ because of the increasing heat rejection subsystem. Figure 13 shows a bar chart mass comparison between a 375 and $425 \mathrm{~K}$ system with a horizontal radiator. Operating at $375 \mathrm{~K}$ results in a 16 percent (50 kg from 35 to $410 \mathrm{kgs})$ mass increase over the minimum mass design. The radiator panel area for the minimum mass design is $8 \mathrm{~m}^{2}$ versus $29 \mathrm{~m}^{2}$ for the $375 \mathrm{~K}$ low temperature system using a horizontal radiator to minimize the GPHS inventory. For comparison going to the higher cold end temperature is an increase in the number of GPHS units required rising from 66 to 73 GPHS modules corresponding to 375 and $425 \mathrm{~K}$ cold end systems and going to the minimum mass system requires 76 GPHS modules.

Figure 14 shows power variation as a function of the lunar day/night cycle for both beginning of life (BOL) and end of life (EOL) operation for a vertically oriented radiator. For this system a life of 10 years is assumed which results in a decrease in thermal power from each GPHS from 250 watts to 234 based on its 87-year half-life. Power variations for this system are approximately 300 watts. For a horizontal radiator the variation in power is about 175 watts due to the smaller overall change in sink temperature. 
Table 3.-5 kWe System Mass Breakdown

\begin{tabular}{|c|c|c|c|c|c|c|}
\hline Component & $\begin{array}{c}375 \mathrm{~K} \\
\text { Cold-End } \\
\text { Horizontal } \\
\text { Radiator }\end{array}$ & $\begin{array}{c}425 \mathrm{~K} \\
\text { Cold-End } \\
\text { Horizontal } \\
\text { Radiator }\end{array}$ & $\begin{array}{c}375 \mathrm{~K} \\
\text { Cold-End } \\
\text { Vertical } \\
\text { Radiator }\end{array}$ & $\begin{array}{c}425 \mathrm{~K} \\
\text { Cold-End } \\
\text { Vertical } \\
\text { Radiator }\end{array}$ & $\begin{array}{c}450 \mathrm{~K} \\
\text { Horizontal } \\
\text { Radiator } \\
\text { Minimum } \\
\text { Mass } \\
\end{array}$ & $\begin{array}{c}450 \mathrm{~K} \\
\text { Vertical } \\
\text { Radiator } \\
\text { Minimum } \\
\text { Mass }\end{array}$ \\
\hline $\begin{array}{c}\text { Stirling } \\
\text { Convertors } \\
\text { (kgs) }\end{array}$ & 45 & 49 & 45 & 49 & 51 & 51 \\
\hline $\begin{array}{c}\text { GPHS Mass } \\
\text { (kgs/no. modules ) }\end{array}$ & $96 / 66$ & $106 / 73$ & $96 / 66$ & $106 / 73$ & $110 / 76$ & $110 / 76$ \\
\hline $\begin{array}{l}\text { GPHS Assembly } \\
\text { Structure } \\
\text { (kgs) }\end{array}$ & 79 & 87 & 79 & 87 & 91 & 91 \\
\hline $\begin{array}{c}\text { GPHS Aluminum } \\
\text { Cover (kgs) }\end{array}$ & 4 & 4 & 4 & 4 & 4 & 4 \\
\hline $\begin{array}{c}\text { Insulation } \\
\text { (kgs) }\end{array}$ & 17 & 19 & 17 & 19 & 18 & 18 \\
\hline $\begin{array}{c}\text { Heat Rejection } \\
\text { (kgs) }\end{array}$ & 146 & 78 & 162 & 50 & 63 & 38 \\
\hline $\begin{array}{c}\text { Power Cond. } \\
\text { (Control + Conv.) } \\
(\mathrm{kgs})\end{array}$ & 27 & 27 & 27 & 27 & 27 & 27 \\
\hline $\begin{array}{c}\text { RadiatorArea }\left(\mathrm{m}^{2}\right) \\
\text { Panel Area }\left(\mathrm{m}^{2}\right)\end{array}$ & $\begin{array}{l}29 \\
29\end{array}$ & $\begin{array}{l}15 \\
15\end{array}$ & $\begin{array}{c}87 \\
43.5\end{array}$ & $\begin{array}{c}23 \\
11.5\end{array}$ & $\begin{array}{l}11 \\
11\end{array}$ & $\begin{array}{c}16 \\
8\end{array}$ \\
\hline Totals & 409 & 366 & 427 & 352 & 360 & 335 \\
\hline
\end{tabular}

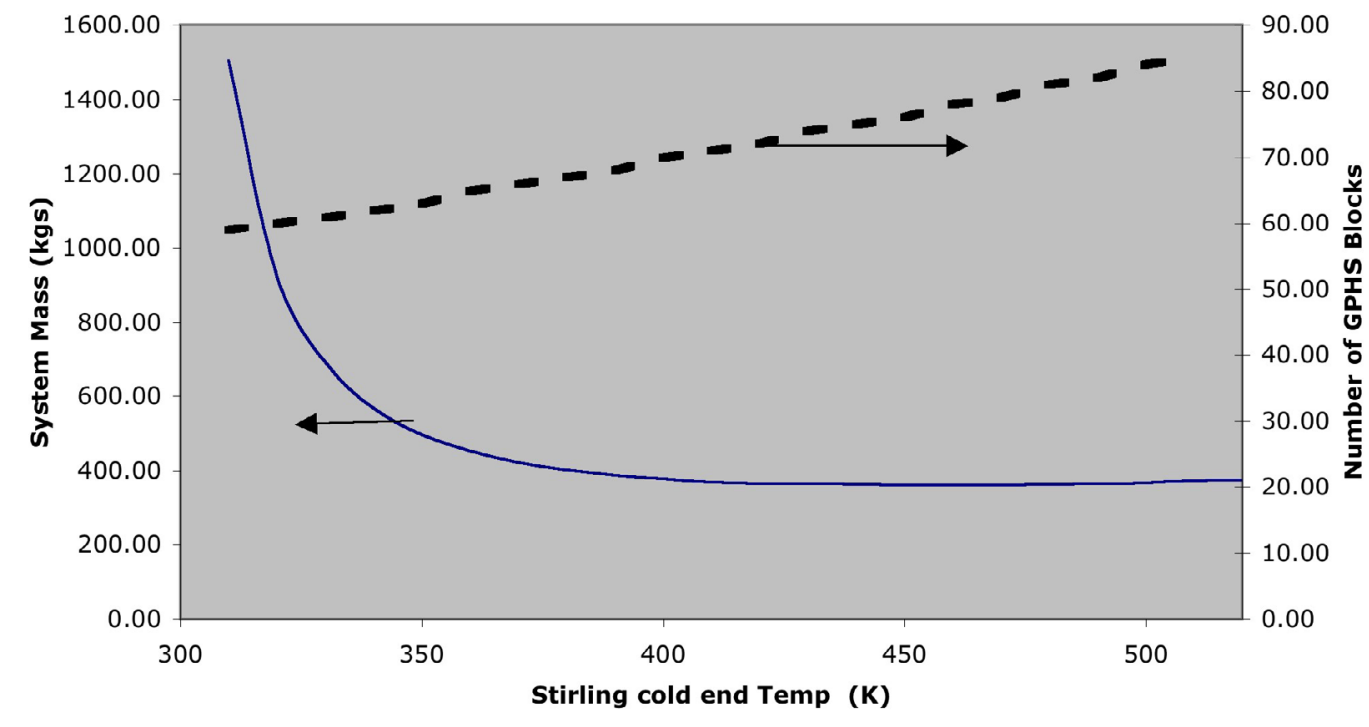

Figure 12.- System mass and number GPHS modules as a function of Stirling cold end temperature for a horizontal radiator. 


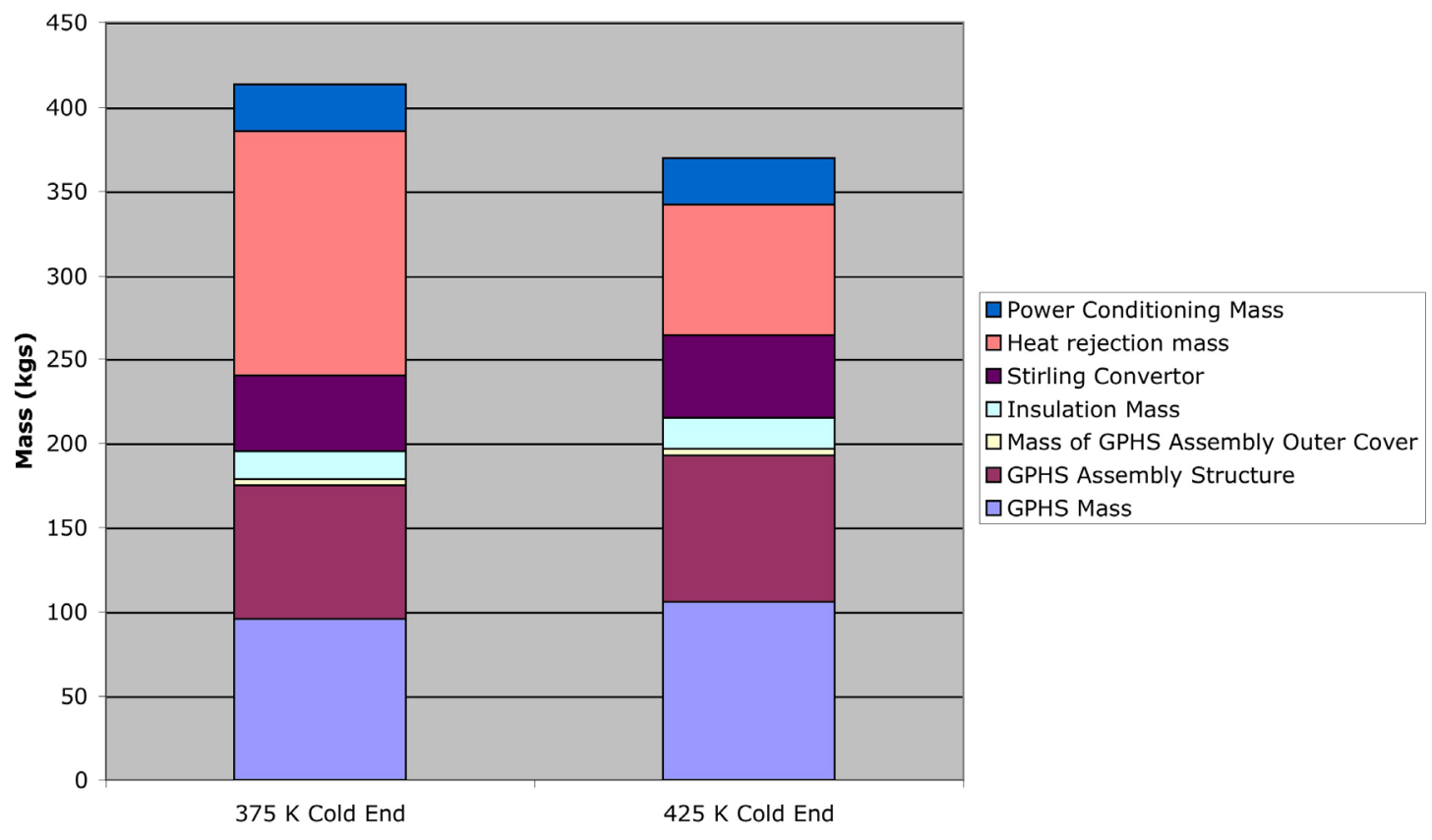

Figure 13.- Mass breakdown for both 375 and $425 \mathrm{~K} 5 \mathrm{KWe}$ systems using a horizontal radiator.

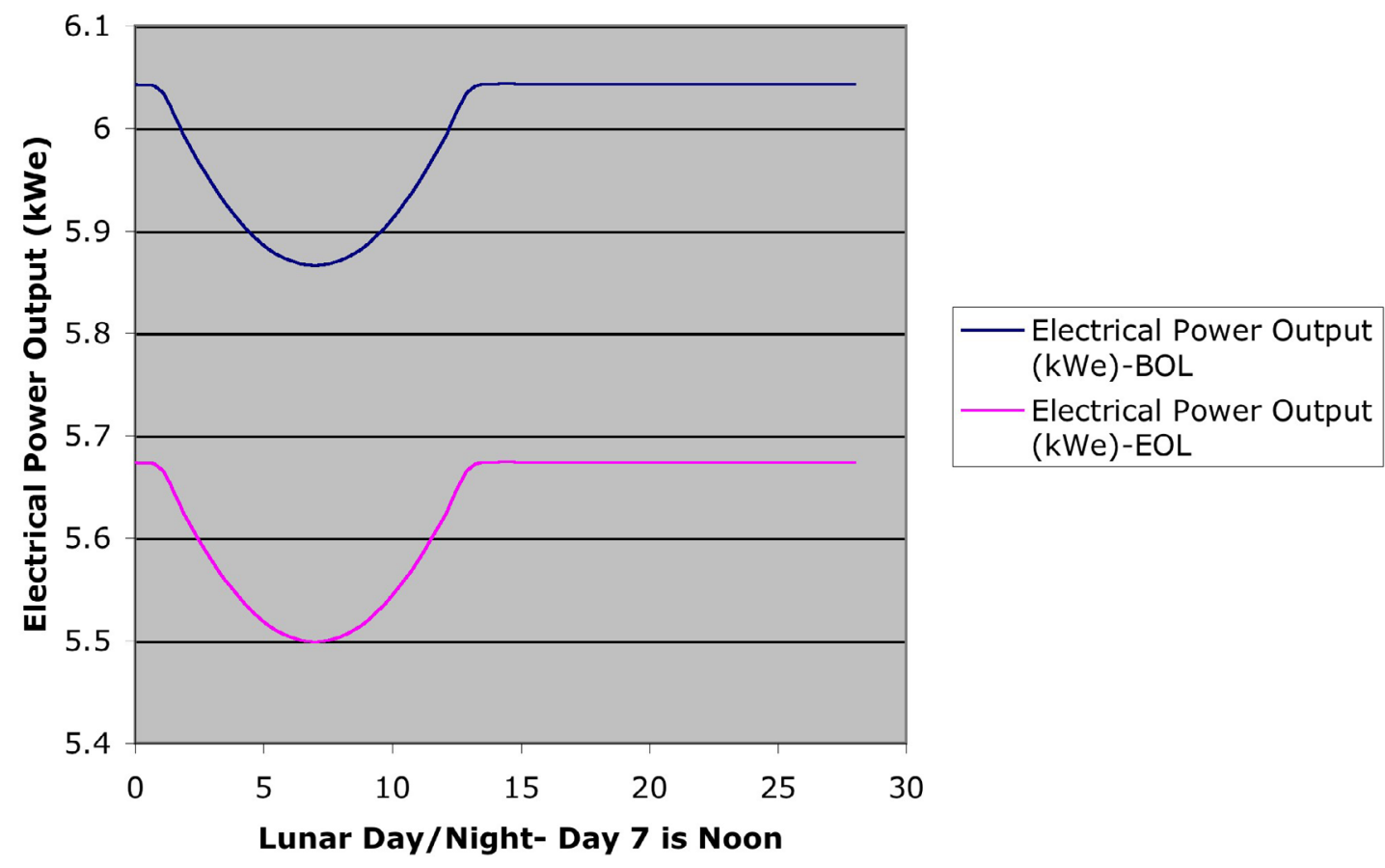

Figure 14.-Beginning of life and end of life power variations as a function of lunar day/night cycle, horizontal radiator. 


\section{Conclusions}

A modular $5 \mathrm{KWe}$ Stirling convertor power system employing GPHS modules as a heat source has been investigated and a reference system configuration identified. This system could have a range of applications in the further exploration of the lunar surface. The proposed system consciously uses currently existing hardware technology or concepts under active investigation at this time. The Stirling convertor itself represents a straightforward adaptation of current technology scaled to higher power levels. The convertor configuration options include both single cylinders and dual-opposed arrangements incorporating proven vibration isolation schemes. The required convertor controller and PMAD systems are an extension of existing technology. A simplified HTS has been identified which minimizes the use of potentially life limiting aspects of high temperature heat pipes while taking full advantage of the available Lunar gravitational field. Various techniques have been selected to ensure that the system would operate reliability under all expected condition.

This approach has a number of advantages compared to other power generation schemes: 1) the GPHS module is fully defined and space launch qualified, 2) emitted radiation is very low and could allowing easy access and placement of the system close to the end user, 3) heat source development costs would be low, and 4) the GPHS heat source can be easily simulated with electrical heaters allowing extensive life testing in existing facilities.

\section{References}

1. Schmidt, G.R., "NASA's Program for Radioisotope Power System Research and Development," STAIF 2005, Albuquerque, NM, 2005.

2. Chan, J., "Stirling Radioisotope Generator (SRG110) Status," STAIF 2005, Albuquerque, NM, 2005.

3. Thieme, L.J. and Schreiber, J.G., "Supporting Development for the Stirling Radioisotope Generator and Advanced Stirling Technology Development at NASA GRC," STAIF 2005, Albuquerque NM, 2005.

4. Dhar, M., "Stirling Space Engine Program," NASA/CR-1999-209164, 1999.

5. Metcalf, K., "Power Management and Distribution (PMAD) Model Development Final Report," NASA Contract NAS3-01140 Rocketdyne, NASA Glenn Research Center, Cleveland, OH, May 2002.

6. Bien, D.D. and Guentert, D.C., "A Method for Reducing the Equivalent Sink Temperature of a Vertically Oriented Radiator on the Lunar Surface," NASA TM X-1729, NASA Lewis Research Center, Cleveland, OH, 1969.

7. Dallas, D., Diaguila, A.J., and Saltsman, J.F., "Design Studies of the Effects of Orientation, Lunation, and Location on the Performance of Lunar Radiators," NASA TM X-1846, NASA Lewis Research Center, Cleveland, OH, 1971. 
Public reporting burden for this collection of information is estimated to average 1 hour per response, including the time for reviewing instructions, searching existing data sources, gathering and maintaining the data needed, and completing and reviewing the collection of information. Send comments regarding this burden estimate or any other aspect of this collection of information, including suggestions for reducing this burden, to Washington Headquarters Services, Directorate for Information Operations and Reports, 1215 Jefferson Davis Highway, Suite 1204, Arlington, VA 22202-4302, and to the Office of Management and Budget, Paperwork Reduction Project (0704-0188), Washington, DC 20503.

\begin{tabular}{|l|l|l|}
\hline 1. AGENCY USE ONLY (Leave blank) & $\begin{array}{c}\text { 2. REPORT DATE } \\
\text { November } 2005\end{array}$ & $\begin{array}{r}\text { 3. REPORT TYPE AND DATES COVERED } \\
\text { Technical Memorandum }\end{array}$ \\
\hline
\end{tabular}

4. TITLE AND SUBTITLE 5. FUNDING NUMBERS

A Design of a Modular GPHS-Stirling Power System for a Lunar Habitation Module

6. AUTHOR(S)

WBS-22-972-20-01

Paul C. Schmitz, L. Barry Penswick, and Richard K. Shaltens

7. PERFORMING ORGANIZATION NAME(S) AND ADDRESS(ES)

National Aeronautics and Space Administration

John H. Glenn Research Center at Lewis Field

Cleveland, Ohio 44135-3191

8. PERFORMING ORGANIZATION REPORT NUMBER

E-15315

9. SPONSORING/MONITORING AGENCY NAME(S) AND ADDRESS(ES)

National Aeronautics and Space Administration

Washington, DC 20546-0001

10. SPONSORING/MONITORING AGENCY REPORT NUMBER

NASA TM-2005-213991

AIAA-2005-5716

11. SUPPLEMENTARY NOTES

Prepared for the Third International Energy Conversion Engineering Conference sponsored by the American Institute of Aeronautics and Astronautics, San Francisco, California, August 15-18, 2005. Paul C. Schmitz, Power Computing Solutions, Inc., 4672 Bellerive Way, Avon, Ohio 44011; L. Barry Penswick, Sest, Inc., 18000 Jefferson Park Road, Suite 104, Middleburg Heights, Ohio 44130; and Richard K. Shaltens, NASA Glenn Research Center. Responsible person, Paul C. Schmitz, organization code RPC, 216-433-6174.

12a. DISTRIBUTION/AVAILABILITY STATEMENT 12b. DISTRIBUTION CODE

Unclassified - Unlimited

Subject Categories: 12 and 20

Available electronically at http://gltrs.grc.nasa.gov

This publication is available from the NASA Center for AeroSpace Information, 301-621-0390.

13. ABSTRACT (Maximum 200 words)

Lunar habitation modules need electricity and potentially heat to operate. Because of the low amounts of radiation emitted by General Purpose Heat Source (GPHS) modules, power plants incorporating these as heat sources could be placed in close proximity to habitation modules. A design concept is discussed for a high efficiency power plant based on a GPHS assembly integrated with a Stirling convertor. This system could provide both electrical power and heat, if required, for a lunar habitation module. The conceptual GPHS/Stirling system is modular in nature and made up of a basic 5.5 KWe Stirling convertor/GPHS module assembly, convertor controller/PMAD electronics, waste heat radiators, and associated thermal insulation. For the specific lunar application under investigation eight modules are employed to deliver $40 \mathrm{KWe}$ to the habitation module. This design looks at three levels of Stirling convertor technology and addresses the issues of integrating the Stirling convertors with the GPHS heat sources assembly using proven technology whenever possible. In addition, issues related to the high-temperature heat transport system, power management, convertor control, vibration isolation, and potential system packaging configurations to ensure safe operation during all phases of deployment will be discussed.

14. SUBJECT TERMS

Isotope; Stirling; Power system; GPHS; General purpose heat source; Lunar base 15. NUMBER OF PAGES 19

\begin{tabular}{|c|c|c|}
\hline $\begin{array}{c}\text { 17. SECURITY CLASSIFICATION } \\
\text { OF REPORT }\end{array}$ & $\begin{array}{c}\text { 18. SECURITY CLASSIFICATION } \\
\text { OF THIS PAGE } \\
\text { Unclassified }\end{array}$ & $\begin{array}{c}\text { 19. SECURITY CLASSIFICATION } \\
\text { OF ABSTRACT } \\
\text { Unclassified }\end{array}$ \\
\hline
\end{tabular}



